\title{
SYNTHESIS AND CHARACTERIZATION OF Co (II) PYRIDINE-2,6-DICARBOXYLATE COMPLEXES AS ANTICANCER COMPOUND
}

\author{
Fahimah Martak ${ }^{1, \bigotimes}$, Endah Mutiara ${ }^{1}$, Mahbub Alwathoni ${ }^{1}$, Triyanda \\ Gunawan $^{1}$ and Soegeng Soegijanto ${ }^{2}$ \\ ${ }^{1}$ Departement of Chemistry, Faculty of Science and Data Analitics, Institut Teknologi Sepuluh \\ Nopember, 60111 Sukolilo, Surabaya, Indonesia \\ ${ }^{2}$ Dengue Study Group, Institut of Tropical Disease, Universitas Airlangga, Kampus C UNAIR, \\ Jalan Mulyorejo, Surabaya 60115, Indonesia \\ ${ }^{\otimes}$ Corresponding Author: fahimahm@chem.its.ac.id
}

\begin{abstract}
In this study, two cobalt [Co(II)] Complexes were synthesized using picolinic acid (2-pyridine carbocyclic) ligand under various $\mathrm{pH}$ conditions. Both Complexes were characterized using FTIR, UV-Vis, XRD, CHNS microanalysis, and thermogravimetric analysis (TGA). The Complex synthesized using metal ion: ligand mol ratio of 1:1 under $\mathrm{pH}$ $\sim 2$ has a molecular formula of $\left[\mathrm{Co}^{\mathrm{II}}(\mathrm{dipic})\left(\mu\right.\right.$-dipic) $\left.-\mathrm{Co}^{\mathrm{II}}\left(\mathrm{H}_{2} \mathrm{O}\right)_{5}\right] \cdot 2 \mathrm{H}_{2} \mathrm{O}$. On the other hand, the Complex synthesized using the higher ligand to metal ratio of 2 at $\mathrm{pH} \sim 1$ has a molecular formula of $\left[\mathrm{Co}^{\mathrm{II}}\left(\mathrm{H}_{2}\right.\right.$ dipic)-(dipic) $] \cdot 3 \mathrm{H}_{2} \mathrm{O}$. The $\left[\mathrm{Co}^{\mathrm{II}}(\mathrm{dipic})\left(\mu\right.\right.$-dipic)-Co $\left.\mathrm{Co}^{\mathrm{II}}\left(\mathrm{H}_{2} \mathrm{O}\right)_{5}\right] \cdot 2 \mathrm{H}_{2} \mathrm{O}$ Complex demonstrating toxicity toward Artemia salina larvae (BSL) with the $\mathrm{LC}_{50}$ value of $5.38 \mathrm{ppm}$. Meanwhile, the $\left[\mathrm{Co}^{\mathrm{II}}\left(\mathrm{H}_{2}\right.\right.$ dipic)-(dipic) $] \cdot 3 \mathrm{H}_{2} \mathrm{O}$ possess an $\mathrm{LC}_{50}$ value of $8.61 \mathrm{ppm}$ against the same larvae. Results showed that the Co (II)-2 Pyridine carbocyclic based Complex synthesized under acid environment demonstrating potential characteristic as anticancer cell

Keywords: Co (II) Complexes, Dipicolinate Ligand, Polymer Complexes, Toxicity Test, Anticancer Compound, BSL Test.
\end{abstract}

RASĀYAN J. Chem., Vol. 14, No.3, 2021

\section{INTRODUCTION}

The study relating to picolinate Complexes showed the biological activity of inducing a murine leukemia HL-60 cell that can delay mycobacterium's ovium Complex growth. ${ }^{1-3}$ Moreover, some reported metalpicolinate Complexes showing an effect in delaying the cancer cells. Van Rijt et al. synthesized Os(II) picolinate to slow the cancer cell growth. ${ }^{4}$ Their result showed that the synthesized Complex has similar properties as cisplatin, widely known as chemotherapy medicine. The $\mathrm{LC}_{50}$ of $\mathrm{Os}$ (II) picolinate value was $4.8 \mu \mathrm{M}$, slightly smaller than the carboplatin $\mathrm{LC}_{50}$ of $6 \mu \mathrm{M}$. The addition of one carbocyclic group in the picolinate ligand ring to produce a diplocinate structure (pyridine-2,6-dicarboxylate) was aimed to improve the toxicity against cancer cells and other bioactivities. To the best of our knowledge, the diplocinate Complexes properties against the cancer cell were not available in the literature. The research was limited to diabetes treatment and antibacterial. The Co (II) pyridine-2,6-dicarboxylates able to reduce the hyperlipidemia in diabetes. ${ }^{5}$ Moreover, reported that the metal dipicoclinate Complex act as the bacteria inhibitor growth. ${ }^{6}$ Thus, this research will carry out diplocinate based Complexes as the anticancer compound. Cobalt is one of the metals in the transition metal group in the periodic table widely used in medicinal chemistry due to the compatibility with the human body and acts as a trace element. ${ }^{5,7,8}$ In this study, cobalt used as an Osmium replacer in the 2-pyridine carboxylate Complexes aims to produce Complexes with similar $\mathrm{LC}_{50}$ (Lethal Concentration) value and better interaction in slowing the cancer cell growth. ${ }^{4}$ The Brine Shrimp Lethality Test (BSLT) is one of the most popular methods for the issue due to easy operation, fast and accurate by utilizing the artemia salina larvae as the test subject.The toxicity test result from the BSLT method usually relates to the cytotoxic of the anticancer compound and expressed in 
RASĀYAN J. Chem.

Vol. 14 | No. 3 |1629-1634| July - September | 2021

$\mathrm{LC}_{50}$ (Lethal Concentration)percent. ${ }^{9-11}$ The compounds are classified as less toxic when the $\mathrm{LC}_{50}$ value in the range of $300-1000 \mathrm{mg} / \mathrm{ml}$ while the $\mathrm{LC}_{50}<100 \mathrm{mg} / \mathrm{ml}$ were for active compounds. ${ }^{11-13}$

\section{EXPERIMENTAL}

\section{Material}

Cobalt chloride $\left(\mathrm{CoCl}_{2} \cdot 6 \mathrm{H}_{2} \mathrm{O}\right)$ as the metal source, diplocinate acid $\left(\mathrm{H}_{2}\right.$ dipic) as ligand, $\mathrm{KBr}, \mathrm{NaOH}, \mathrm{HCl}$, $\mathrm{HNO}_{3}$ as $\mathrm{pH}$ controller demineralized water, and ethanol absolute, which were purchased from Merck. $\mathrm{CoCl}_{2}$ (anhydrous) was obtained from the calcined of $\mathrm{CoCl}_{2} \cdot 6 \mathrm{H}_{2} \mathrm{O}$ at a temperature of $140^{\circ} \mathrm{C}$ for 4 hours. The toxicity test was conducted on shrimp larvae Artemia salina, and the seawater was taken from Kenjeran beach in Surabaya, Indonesia.

\section{Methods}

The $\mathrm{Co}^{\mathrm{II}}$ (dipic)( $\mu$-dipic) $\left.\mathrm{Co}^{\mathrm{II}}\left(\mathrm{H}_{2} \mathrm{O}\right)_{5}\right] \cdot 2 \mathrm{H}_{2} \mathrm{O}(1)$ Complex was synthesized from the reaction of $\mathrm{CoCl}_{2}$ and $\mathrm{H}_{2}$ dipic with the ratio of 1:1 under acid environment $(\mathrm{pH}=1-3)$. The [ $\mathrm{Co}^{\mathrm{II}}\left(\mathrm{H}_{2}\right.$ dipic $)$ dipic] $3 \mathrm{H}_{2} \mathrm{O}$ Complex was synthesized by reacting $\mathrm{CoCl}_{2} \cdot 6 \mathrm{H}_{2} \mathrm{O}$ and $\mathrm{H}_{2}$ dipic with a molar ratio of $1: 2$. The solution was conditioned at $\mathrm{pH}=1-3$ by adding $\mathrm{HCl} 5 \mathrm{M}$. The solution was stirred at a temperature of $90^{\circ} \mathrm{C}$ for $2 \mathrm{~h}$, cooled naturally afterward, and followed by aging for 5 days. Finally, the solution was filtered and recrystallized using demineralized water followed by drying at ambient conditions.

The Complexes characterization was involving ${ }^{1} \mathrm{H}$ NMR (Bruker AMX $400 \mathrm{NMR}$ at $400 \mathrm{MHz}$ ), UV-Vis (Thermo scientific-Genesys 10S), X-ray diffractogram (CuK $\alpha$ radiation, $\lambda=0.154 \AA$ at $40 \mathrm{kV}$ and $30 \mathrm{~mA}$ ) on an Expert PAN Analytical, Atomic Adsorption Spectroscopy (Shimadzu AA-680), the thermal stability of the Complexes were evaluated using Thermal gravimetric analysis (Mettler Toledo TGA/SDTA 851). The lethal concentration $\left(\mathrm{LD}_{50}\right)$ of the synthesized Complexes was determined using Brine Shrimp Lethality (BSL) method. ${ }^{13}$ The $\mathrm{LD}_{50}$ was measured by varying the concentration $(0,1,10,100$, and $1000 \mathrm{ppm})$ of Complex (1) and (2) as gram-positive and repeated five times with the contact time of $24 \mathrm{~h}$.

\section{Effect of pH in the Complex Formation}

\section{RESULTS AND DISCUSSION}

The binuclear Complex of $\left[\mathrm{Co}^{\mathrm{II}}(\right.$ dipic $)\left(\mu\right.$-dipic) $\left.\mathrm{Co}^{\mathrm{II}}\left(\mathrm{H}_{2} \mathrm{O}\right)_{5}\right] \cdot x \mathrm{H}_{2} \mathrm{O}$ formation was initiated at the $\mathrm{pH}=1$ and increasing as the acidity level decreased. The maximum absorbance was observed at $\mathrm{pH}=3$ with maximum wavelength and absorbance of $\left(\lambda_{\text {maks }}\right) 496 \mathrm{~nm}$ and 0.115 . Thus, the Complex (1) was formed at the optimum $\mathrm{pH}=3$. The increment of basic $(\mathrm{NaOH})$ lead to the deprotonation of $\mathrm{H}_{2}$ dipic from ligand into dipic $\mathrm{c}^{2-i o n}$ and is followed by the coordination formation of $\mathrm{Co}$ in the Oxygen donor atom to form the binuclear Complex of $\left[\mathrm{Co}^{\mathrm{II}}\left(\right.\right.$ dipic) $\left(\mu\right.$-dipic)- $\left.\mathrm{Co}^{\mathrm{II}}\left(\mathrm{H}_{2} \mathrm{O}\right)_{5}\right] \cdot x \mathrm{H}_{2} \mathrm{O}$. NaOH was chosen as a basic reagent due to the $\mathrm{Na}^{+}$has high solubility. The addition of $\mathrm{NH}_{3}$ was also conducted to increase the $\mathrm{pH}$. The Complex with $\mathrm{NH}_{3}$ addition posses a luteo (yellowish) color, and it is suggested that $\mathrm{CoCl}_{2} .6 \mathrm{NH}_{3}$ was formed.

In the Complex (2) formation, the optimum $\mathrm{pH}$ condition was observed at $\mathrm{pH} 1.0$ as indicated with the highest absorbance value at the maximum wavelength of the Complex (2) formation $\left(\lambda_{\text {maks }}\right) 465 \mathrm{~nm}$. At $\mathrm{pH}$ 1.0, most of the pyridine-2.6 dicarboxylate acid was protonated into dipic ${ }^{2-}$ ion. The rest was not protonated and still in the $\mathrm{H}_{2}$ (dipic) form after forming coordination bonding with the central cobalt atom. The absorbance value at fewer acid conditions ( $\mathrm{pH} 1.5$ and 2.0) was decreased. The significant absorbance value drop was further observed at a later stage $(\mathrm{pH} 2.5$ dan 3.0) and suggested the other cobalt-dipicolinate Complexes' formation. The possibility of the other cobalt Complex such as $\left[\mathrm{Co}(\right.$ dipic) $] \cdot 3 \mathrm{H}_{2} \mathrm{O}$ was observed at higher $\mathrm{pH}$ conditions of the metal: ligand reaction. ${ }^{5}$

\section{The AAS Analysis}

The light element analysis of each Complex was listed in Table. The Complex (1) element composition synthesized in this study was close to the calculated structure of $\left[\mathrm{Co}\right.$ (dipic) $\left(\mu\right.$-dipic) $\left.\mathrm{Co}\left(\mathrm{H}_{2} \mathrm{O}\right)_{5}\right] .2 \mathrm{H}_{2} \mathrm{O}$, which indicated a similar amount in cobalt element. However, a slight difference in the $\mathrm{C}, \mathrm{H}$, and $\mathrm{N}$ percentage of the Complex (1) compared to the calculated structure was due to the impurities present, resulting in a lower amount of those elements than its calculated structure. Despite having a lower ligand to metal ratio of 1, the cobalt amount in the Complex (1) has a higher amount (20.34\%) as compared to the Complex (2), $12.77 \%$, which successfully synthesized at a higher ligand to metal ratio of 2 . This result indicated that 
RASĀYAN J. Chem.

Vol. 14 | No. 3 |1629-1634| July - September | 2021

Complex (1) possesses two nuclei (binuclear) of the central cobalt atom, while Complex (2) has one nucleus (mononuclear). The Complex (2) light element composition was close to the theoretically calculated structure of $\left[\mathrm{Co}\left(\mathrm{H}_{2}\right.\right.$ dipic) $($ dipic $\left.)\right] .3 \mathrm{H}_{2} \mathrm{O}$ with a percentage difference of less than $0.5 \%$. This result confirms the assumption that Complex (2) is a mononuclear Complex while Complex (1) is a binuclear Complex. The $\mathrm{pH}$ and ligand to metal ratio were essential in determining the final product of the cobalt-dipicolinate based Complexes.

\begin{tabular}{|c|c|c|c|c|}
\hline Molecular Formula & $\% \mathrm{Co}$ & $\% \mathrm{C}$ & $\% \mathrm{H}$ & $\% \mathrm{~N}$ \\
\hline \multicolumn{5}{|c|}{ Complex (1) } \\
\hline Sample (experiment) & 20.34 & 28.82 & 3.42 & 4.64 \\
\hline$\left[\mathrm{Co}(\right.$ dipic $)(\mu$-dipic $\left.) \mathrm{Co}\left(\mathrm{H}_{2} \mathrm{O}\right)_{5}\right] \cdot 2 \mathrm{H}_{2} \mathrm{O}$ & 20.52 & 29.28 & 3.51 & 4.87 \\
\hline \multicolumn{5}{|c|}{ Complex (2) } \\
\hline Sample (experiment) & 12.77 & 37.98 & 3.31 & 6.96 \\
\hline$\left[\mathrm{Co}\left(\mathrm{H}_{2}\right.\right.$ dipic $)($ dipic $\left.)\right] .3 \mathrm{H}_{2} \mathrm{O}$ & 13.23 & 37.76 & 3.16 & 6.29 \\
\hline
\end{tabular}

\section{The FTIR Analysis of Synthesized Complexes}

Fig.-1 shows the FTIR spectra of both Complexes. The broad peak at wavenumber around $3448-3101.54$ $\mathrm{cm}^{-1}$ corresponds to the $\mathrm{O}-\mathrm{H}$ from the Complexes crystal water and water ligand. The $\mathrm{C}=\mathrm{N}$ vibration of the pyridine ring in the Complex (1) was observed at the peak at $1620-1630 \mathrm{~cm}^{-1}$. ${ }^{14}$ Medium peak intensity observed at $1712.79 \mathrm{~cm}^{-1}$ refers to the $\mathrm{C}=\mathrm{O}$ vibration in the carboxylic group. The formation of the binuclear Complex (1) was confirmed in the peak that appeared at $1080.14 \mathrm{~cm}^{-1}$, which corresponds to the Co-O vibration with $\mathrm{O}$-dipicolinate as a bridging ligand. In comparison, the coordination bonding of oxygen with Co was observed at 424.37 and $331.76 \mathrm{~cm}^{-1}$. The strong absorption peak at $686.66 \mathrm{~cm}^{-1}$ corresponded to the Co-N vibration ${ }^{5}$. Similar peaks were also observed in the FTIR spectra of Complex (2). The noticeable differences were in the fingerprint region of $1400-300 \mathrm{~cm}^{-1}$. The peak observed at $671.23-432.05$ and $316.33 \mathrm{~cm}^{-1}$ were referred to as the $\mathrm{Co}-\mathrm{O}$ and $\mathrm{Co}-\mathrm{N}$ vibrations, respectively. Moreover, a significant difference was observed in the C-C peaks at $1373.32 \mathrm{~cm}^{-1}$. The Complex (2) low rigidity structure leads to the higher absorption peak of $\mathrm{C}-\mathrm{C}$ and $\mathrm{C}-\mathrm{O}$ compared to the Complex (1).
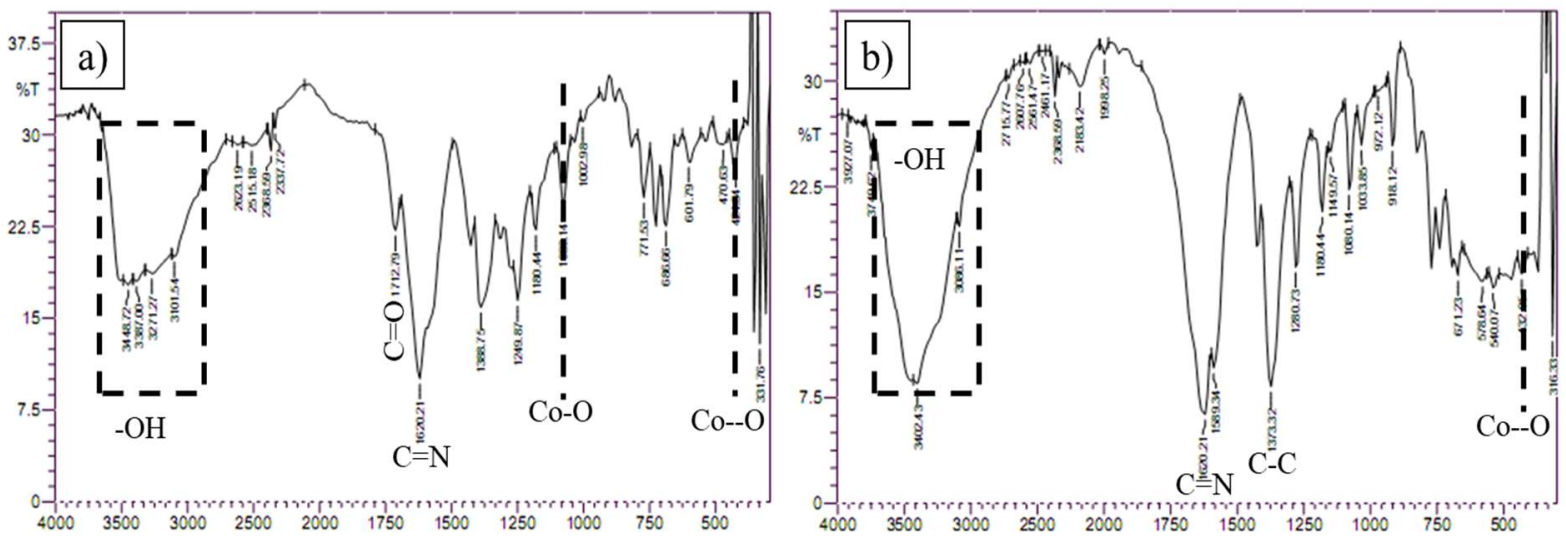

Fig.-1:FTIR Spectra of Complex (a) (1) and (b) (2)

\section{XRD Analysis of the Synthesized Complexes}

The diffraction pattern of both Complexes was shown in Fig. The Complex (1) diffractogram pattern showed high-intensity peaks that indicated high crystallinity of the synthesized Complex. The nine highest peaks were further analyzed with the FULPROF 2006 software. The resulting calculation was that the crystal has a monoclinic shape with the space group of $\mathrm{P} 2 / \mathrm{m}, \mathrm{a}=13.36, \mathrm{~b}=3.23, \mathrm{c}=8.62$. The Complex (2) diffractogram pattern shows different patterns compared to the Complex (1), which confirms that both Complexes have a different crystal structure. The analysis result showed that the crystal has a similar monoclinic shape with the space group $\mathrm{P} 2 / \mathrm{m}, \mathrm{a}=11.06, \mathrm{~b}=11.61$, and $\mathrm{c}=6.46$, which was consistent with the single crystal data reported previously. ${ }^{5,15}$ Overall, the XRD study confirms that both Complexes have been successfully synthesized with high crystallinity. 
RASĀYAN J. Chem.

Vol. 14 | No. 3 |1629-1634| July - September | 2021
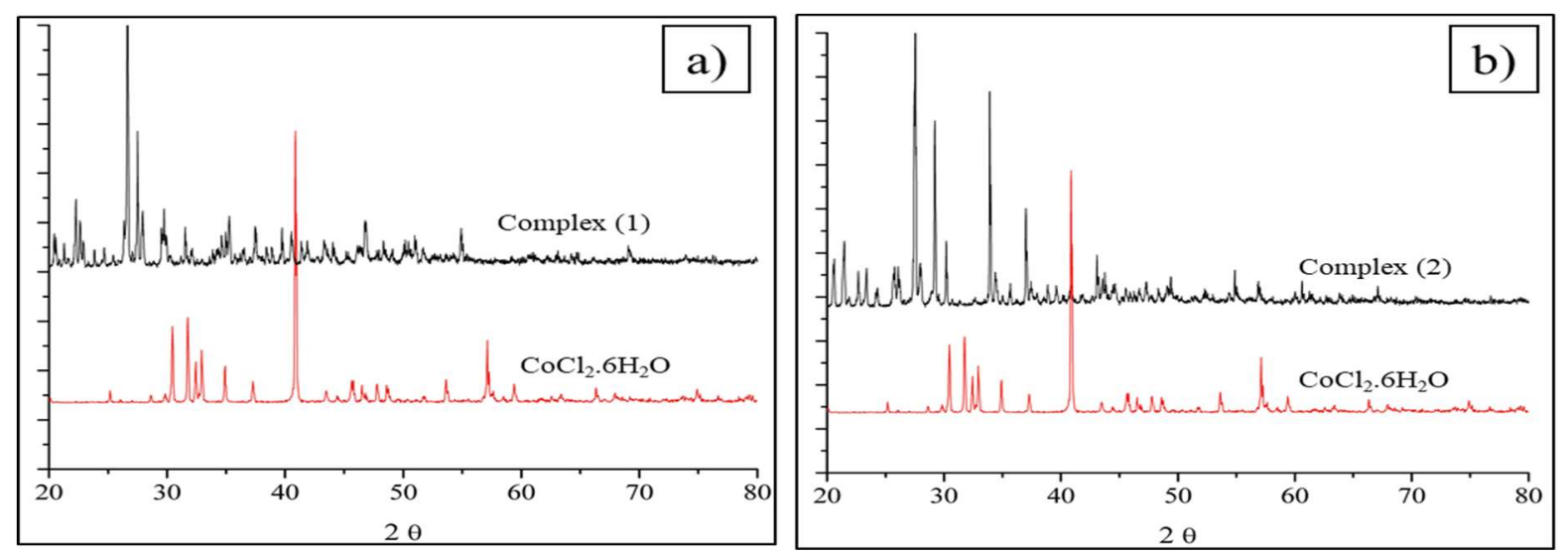

Fig.-2: Diffractogram Pattern of Complex (a) (1) and (b) (2)

\section{Thermogravimetric Study of the Complexes}

Fig shows the thermograph profile of the synthesized Complexes. The thermograph profile of both Complexes showing a similar trend. The first mass loss occurred at a temperature of $70-120^{\circ} \mathrm{C}$, which refers to the Complex crystal water loss. The mass reduction in this stage was equal to the $\sim 3$ mol of crystal water. The second step was the decomposition of the $\mathrm{H}_{2}$ dipic $(\sim 0.5 \mathrm{~mol})$, which occurred at a temperature of 220 $280^{\circ} \mathrm{C}$. The last step was the ligand of pyridine-2,6-dicarboxylate loss at a temperature of $360-480^{\circ} \mathrm{C}$. Theoretically, $1 \mathrm{~mol}$ of dipic ligand equal to the $37.1 \%$ mass, thus it was confirmed that the third mass reduction referred to the $1 \mathrm{~mol}$ of dipic ligand. The residue around $31.5 \%$ corresponded to the cobalt and the undecomposed ligand, and theoretically, $1 \mathrm{~mol}$ of Co and $0.5 \mathrm{~mol}$ of dipic equal to the $31.76 \%$ total mass of the Complex. Overall, the Complex thermographic profile was consistent with the dipic-based Complex reported previously. ${ }^{5,16}$
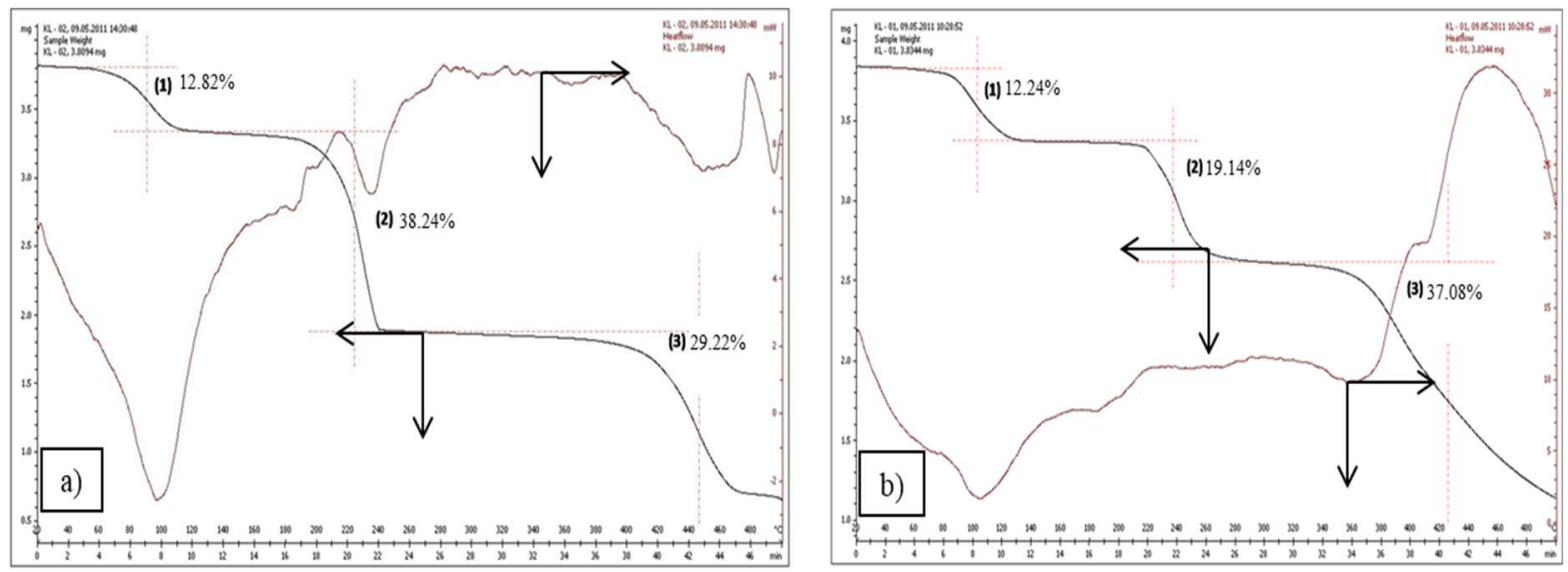

Fig.-3: The Thermograph Profile of the Complex (a) (1) and (b)(2)

\section{Structure of the Complexes}

Based on the characterization data discussed previously, the synthesized Complexes molecular structure was illustrated in Fig.-2. The computational approaches toward the diffractogram data showed the single crystal and spacing groups similar to the monoclinic $\mathrm{P} 2 / \mathrm{m} .{ }^{5}$ The thermograph profile matched with the AAS analysis in terms of total residue produced after the heating process. Similar to the Complex (1), all the characterization data of the Complex (2) strongly suggest that the structure of the Complex was $\left[\mathrm{Co}\left(\mathrm{H}_{2}\right.\right.$ dipic $)($ dipic $\left.)\right] .3 \mathrm{H}_{2} \mathrm{O}$. The AAS analysis showed a difference in element content with less than $0.5 \%$ compared to the simulated structure.

Moreover, the FTIR spectra revealed less O-H from the water molecule $\left(3402.43 \mathrm{~cm}^{-1}\right)$ than the Complex (1). The monoclinic P $2 / \mathrm{m}$ crystal system. The percentage of residue in the thermograph profile of the Complex (2) matched with the AAS data that suggests the structure of the Complex (2) was $\left[\mathrm{Co}\left(\mathrm{H}_{2}\right.\right.$ dipic $)($ dipic $\left.)\right] .3 \mathrm{H}_{2} \mathrm{O}$. 

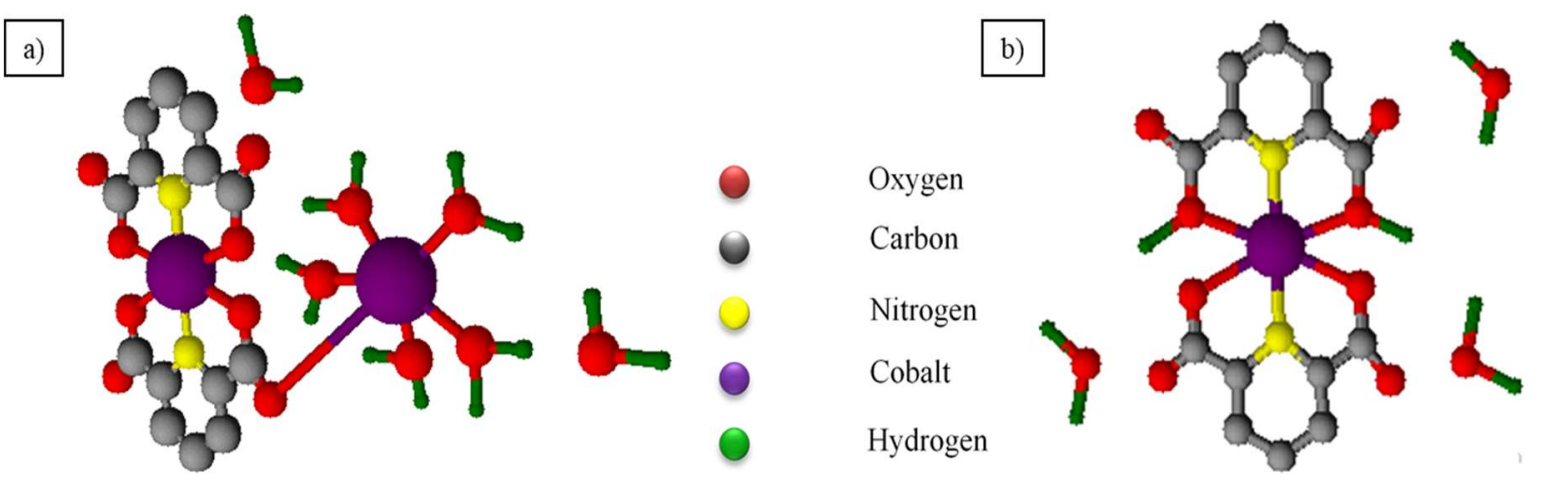

\section{Toxicity Test}

Fig.-2 Structure Prediction of Synthesized Complex (a) (1) and (b) (2)

The Complex concentration treatment led to the disorientation movement of Artemia, which was spinning at one point. The factors that caused the Artemia to fall was an external factor that was outside the researcher control. As can be seen in Fig. -3 , the linear regression obtained were $y=0.0451 x-1.519$ and $y=0.049 x-$ 1.516 for Complex (1) and (2), respectively. Thus, the $\mathrm{LD}_{50}$ value of the Complex (1) and (2) was 5.38 and 8.61 , respectively.
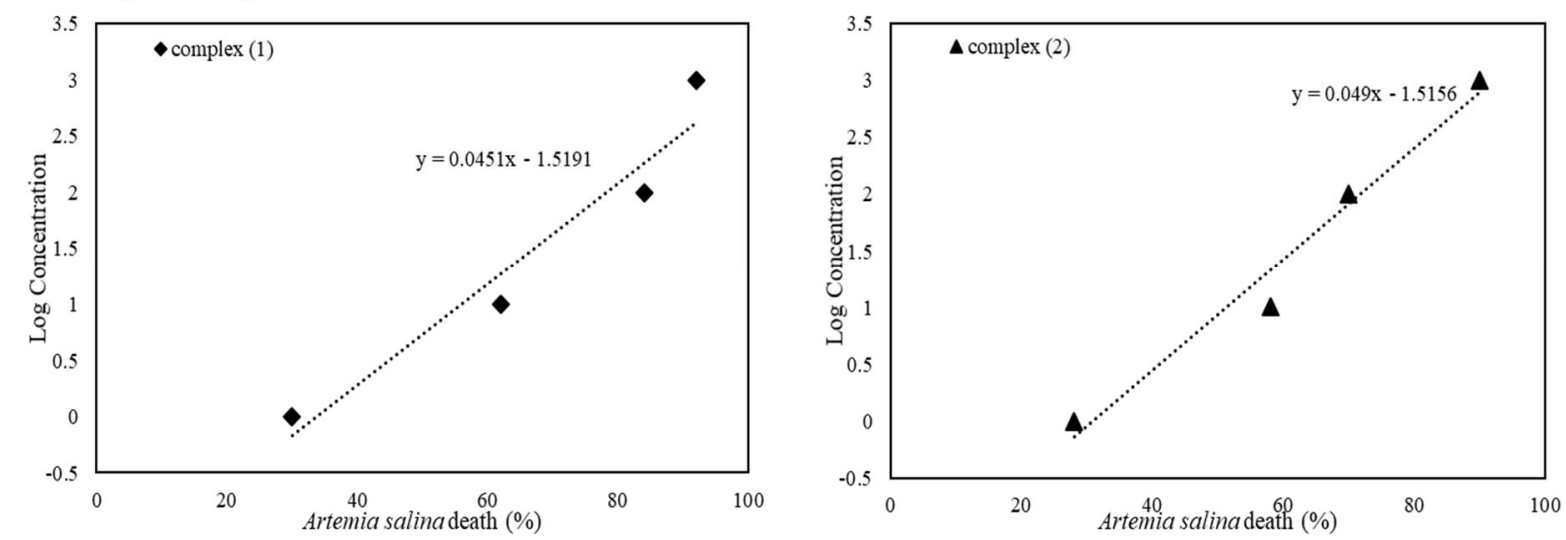

Fig.-3 The Toxicity Properties of the Synthesized Complexes

A compound could show toxicity properties in the BSL test if it caused $50 \%$ death of subject test $\left(\mathrm{LC}_{50}\right)$ in less than $1000 \mu \mathrm{g} / \mathrm{ml}$ sample concentration, while the pure compound was $\mathrm{LC}_{50}<200 \mu \mathrm{g} / \mathrm{ml} .{ }^{10}$ Based on the parameters mentioned above, the sample of Cobalt(II) chloride, [Co(dipic)( $\mu$-dipic) $\left.\mathrm{Co}\left(\mathrm{H}_{2} \mathrm{O}\right)_{5}\right] \cdot 2 \mathrm{H}_{2} \mathrm{O}$ (1) and $\left[\mathrm{Co}\left(\mathrm{H}_{2}\right.\right.$ dipic)-(dipic) $] \cdot 3 \mathrm{H}_{2} \mathrm{O}$ (2) showing high toxicity against BSL sample. The binuclear Complex of $\left[\mathrm{Co}\right.$ (dipic) $\left(\mu\right.$-dipic) $\left.\mathrm{Co}\left(\mathrm{H}_{2} \mathrm{O}\right)_{5}\right] \cdot 2 \mathrm{H}_{2} \mathrm{O}(1)$ showed the highest $\mathrm{LC}_{50}$ of $5.38 \mathrm{ppm}$. The Complex (1) possessed two ligand types of dipicolinate and aqua. Aqua ligand has coordination interaction with cobalt and a weak ligand that is easily substituted by integral protein from membrane cell. This results in the blocking of the $\mathrm{Na}^{+}$dan $\mathrm{K}^{+}$active transport. Stopped active transport led to the uncontrollable $\mathrm{Na}^{+}$ion entrance and caused membrane cell breaking. ${ }^{14,17,18}$ It is suggested that the hydrogen bonding in the Complex (1) contributed to reducing $\mathrm{LC}_{50}$ value. The hydrogen bonding deteriorated the membrane cell through the groove binding mechanism. This mechanism was highly influenced by the Complex molecule molecular geometry that interacted with the DNA and the electric field around the DNA framework, Van der Waals forces, hydrogen bonding, and hydrophobic effect. ${ }^{8}$ For Complex (2), the -OH groups from dipicolinate ligand bonded with the integral protein from the membrane cell and destroys the cell.

\section{CONCLUSION}

Two Complexes based on the cobalt (II) pyridine-2,6-dicarboxylate have been synthesized. The characterization results showed that the Complexes have a molecular formula of [Co ${ }^{\mathrm{II}}(\mathrm{dipic})(\mu$-dipic)$\left.\mathrm{Co}^{\mathrm{II}}\left(\mathrm{H}_{2} \mathrm{O}\right)_{5}\right] \cdot 2 \mathrm{H}_{2} \mathrm{O}(1)$ and $\left[\mathrm{Co}^{\mathrm{II}}\left(\mathrm{H}_{2}\right.\right.$ dipic $)($ dipic $\left.)\right] \cdot 3 \mathrm{H}_{2} \mathrm{O}(2)$. Complex (1) was formed at optimum $\mathrm{pH}$ of 3 and yield of $47.9 \%$, while Complex (2) was formed at optimum pH of 1 and a yield of $50.45 \%$. Complex (1) 
RASĀYAN J. Chem.

Vol. 14 | No. 3 |1629-1634| July - September | 2021

have binuclear with the mixed ligand, while Complex (2) was mononuclear with one type of ligand. Based on the toxicity test on Brine Shrimp Lethality (BSL), the binuclear Complex of [Co(dipic)( $\mu$ dipic) $\left.\mathrm{Co}\left(\mathrm{H}_{2} \mathrm{O}\right)_{5}\right] \cdot 2 \mathrm{H}_{2} \mathrm{O}(1)$ exhibited an $\mathrm{LC}_{50}$ value of $5.38 \mathrm{ppm}$, while for Complex (2) showed $\mathrm{LC}_{50}$ value of $8.61 \mathrm{ppm}$. The binuclear interaction, groove binding, intercalation, and lower $\mathrm{LC}_{50}$ value of Complex (1) indicated more toxic properties than Complex (2). Thus, it can be concluded that the binuclear system of the Co-dipicolinate based Complex shows promising characteristics as the new anticancer compounds.

\section{ACKNOWLEDGEMENT}

The author acknowledges the Ministry of Research, Technology, and Higher Education of Indonesia for supporting the research under PDUPT (Penelitian Dasar Unggulan Perguruan Tinggi) grant, contract number: 881/PKS/ITS/2018, as well as the financial support from Hibah Riset Mandat Universitas Airlangga, 2019 grant, contract number: 380/UN3/14LT/2019.

\section{REFERENCES}

1. A. M. Hamil, K. M. Khalifa, A. Al-Houni, and M. M. El-Ajaily, Rasayan Journal of Chemistry, 2(2), 261(2009).

2. P. Rajkumar, G. Saraswathy, Z. Abdul Vaheith, and A. Fiaz Ahamed, Rasayan Journal of Chemistry, 12(3), 1127(2019), https://doi.org/10.31788/RJC.2019.1235318

3. G. R. Pandhare, V. M. Shinde, and Y. H. Deshpande, Rasayan Journal of Chemistry, 1(2), 337(2008).

4. S. H. van Rijt, A. F. A. Peacock, R. D. L. Johnstone, S. Parsons, and P. J. Sadler, Inorganic Chemistry, 48(4), 1753(2009), https://doi.org/10.1021/ic8020222

5. L. Yang, D. C. Crans, S. M. Miller, A. La Cour, O. P. Anderson, P. M. Kaszynski, M. E. Godzala, L. T. D. Austin, and G. R. Willsky, Inorganic Chemistry, 41(19), 4859(2002), https://doi.org/10.1021/ic0200621

6. A. T. Çolak, F. Çolak, O. Z. Yeşilel, and O. Büyükgüngör, Journal of Molecular Structure, 936(1-3), 67(2009), https://doi.org/10.1016/j.molstruc.2009.07.026

7. F. Blasco, L. Perelló, J. Latorre, J. Borrás, and S. Garciá-Granda, Journal of Inorganic Biochemistry, 61(2), 143(1996), https://doi.org/10.1016/0162-0134(95)00053-4

8. B. J. Pages, D. L. Ang, E. P. Wright, and J. R. Aldrich-Wright, Dalton Transactions, 44(8), 3505(2015), https://doi.org/10.1039/C4DT02700K

9. S. A. Gadir, Journal of Chemical and Pharmaceutical Research, 4(12), 5145(2012).

10. J. J. Martínez Medina, L. G. Naso, A. L. Pérez, A. Rizzi, N. B. Okulik, M. Valcarcel, C. Salado, E. G. Ferrer, and P. A. M. Williams, Biomedicine and Pharmacotherapy, 111, 414(2019), https://doi.org/10.1016/j.biopha.2018.12.098

11. S. Muthukrishnan, T. Senthil Kumar, and M. V. Rao, Journal of Environmental Chemical Engineering, 5(2), 1685(2017), https://doi.org/10.1016/j.jece.2017.03.004

12. T. ur Rehman, A. U. Khan, A. Abbas, J. Hussain, F. U. Khan, K. Stieglitz, and S. Ali, Saudi Pharmaceutical Journal, 26(3), 422(2018), https://doi.org/10.1016/j.jsps.2017.12.019

13. S. Pisutthanan, P. Plianbangchang, N. Pisutthanan, S. Ruanruay, and O. Muanrit, Naresuan University Journal, 12(2), 13(2004).

14. A. Klanicová, Z. Trávníček, I. Popa, M. Čajan, and K. Doležal, Polyhedron, 25(6), 1421(2006), https://doi.org/10.1016/j.poly.2005.09.032

15. A. Geete, B. D. Shrivastava, and A. Mishra, Rasayan Journal of Chemistry, 13(3), 1878(2020), https://doi.org/10.31788/RJC.2020.1335777

16. Z. A. Siddiqi, M. Khalid, S. Kumar, M. Shahid, and S. Noor, European Journal of Medicinal Chemistry, 45(1), 264(2010), https://doi.org/10.1016/j.ejmech.2009.10.005

17. P. C. Harrington and R. G. Wilkins, Journal of Inorganic Biochemistry, 12(2), 107(1980), https://doi.org/10.1016/S0162-0134(00)80122-1

18. İ. Uçar, A. Bulut, A. Karadăg, and C. Kazak, Journal of Molecular Structure, 837(1-3), 38(2007), https://doi.org/10.1016/j.molstruc.2006.09.029

[RJC-5823/2020] 